Article

\title{
Towards a Valuation and Taxation Information Model for Chinese Rural Collective Construction Land
}

\author{
Zhongguo $\mathrm{Xu}^{1,2}$, Yuefei Zhuo ${ }^{1,2, * \mathbb{C}}$, Guan $\mathrm{Li}^{3}{ }^{\mathbb{D}}$, Rong Liao ${ }^{1,4}$ and Cifang $\mathrm{Wu}^{1,2}$ \\ 1 Department of Land Administration, School of Public Affairs, Zhejiang University, Hangzhou 310058, China; \\ mailxzg@zju.edu.cn (Z.X.); Rosyliao@zju.edu.cn (R.L.); wucifang@zju.edu.cn (C.W.) \\ 2 Land Academy for National Development, Zhejiang University, Hangzhou 310029, China \\ 3 Law School, Ningbo University, Ningbo 315211, China; liguan@nbu.edu.cn \\ 4 Department of Foreign Affairs, China Land Surveying and Planning Institute, Beijing 100035, China \\ * Correspondence: yfzhuo@zju.edu.cn
}

Received: 1 October 2019; Accepted: 8 November 2019; Published: 22 November 2019

\begin{abstract}
To promote rural revitalisation, China's central government revised the land administration law to allow rural collective construction land (RCL) to be traded in the market and attract private and financial capitals into rural investment and development. However, the land value appreciation income of the market access is closely related to geographical location. Hence, the value appreciation of RCL is enormous in villages around cities and towns. By contrast, the land value appreciation of $\mathrm{RCL}$ is low in villages away from cities and towns. This marked difference will lead to a significant impact on the rural social structure. To avoid the excessive widening of the income gap in rural areas, China's central government attempted to conduct land value capture by revising and implementing land tax laws and reasonably distributing the value appreciation income of market access amongst the state, collectives and individuals. In response to the requirements of land reform, this study firstly identifies the legal constraints on the taxation of RCL in China through the structured retrieval and organisation of legal documents on land taxation. Thereafter, the technical constraints are analysed through the structural retrieval and organisation of the technical specifications of China's land valuation. Lastly, this study proposes a land administration domain model (LADM) valuation and taxation information model on the basis of the aforementioned constraints. The major contents of the proposed model encompass improving the information management of taxpayer identity registration, supplementing land valuation methods and strengthening valuation information of the large-scale influencing factors. The proposed model is the technical basis to prompt the interconnection between the real estate registration and real estate taxation systems, which will be conducive to the efficient collaboration of the two systems.
\end{abstract}

Keywords: valuation and taxation model; land value capture; LADM; rural collective construction land; China

\section{Introduction}

Land administration constitutes three core components: land tenure, land use and land value [1,2]. Land value management refers to the administrative behaviours that provide the local government with financial resources through collecting property tax on land and its attached objects [1]. Globally, stable land taxes have constantly been reliable financial sources for local governments to provide public goods (services). Stable land tax is also conducive to incentivising and constraining local governments to effectively respond to public requirements. Therefore, land value management plays a significant role in improving land governance and social sustainability [2]. Cadastre has consistently been the core and foundation of land administration system [3]. From a global perspective, 
the cadastral system has undergone a complicated historical process (i.e., fiscal, legal and multi-purposes cadastre) [2-4]. Accordingly, cadastre can be considered a reliable information source for land taxation since its introduction [4]. Therefore, cadastre and land tax have been closely related and the information management of land value has constantly been an important component of cadastre [2]. For example, land valuation and taxation extension model are included in the international standard land administration domain model (LADM) [5]. Additionally, Commissions 7 and 9 of the International Federation of Surveyors (FIG) are jointly developing the upgraded version of the LADM land valuation and taxation extension model and preparing to absorb relevant research results into the LADM Edition II $[6,7]$. The New Working Proposal for the LADM Edition II submitted to ISO ITC 211 contains the content of the land valuation and taxation information model [7]. Therefore, the study of land valuation and taxation information model has strong theoretical and practical demands [8]. For China, rural land administration has been performing poorly for a long time [9]. After the reform and opening up, China's urbanisation and industrialisation have attracted many people from the countryside to the city. Consequently, the countryside was marginalised and hollowed out [10]. To revitalise the countryside, China's central government has attempted to open up the rural collective construction land (RCL) market to attract external funds, talents and projects into the countryside, thereby providing production factors for countryside revitalisation [11]. On the one hand, the protection of land tenure should be conducted, a vigorous land market should be built and social and financial capital investments in rural lands should be attracted [11]. On the other hand, the opening up of the land market has brought the urgent practical problem of rapidly widening income gap between the rich and poor [12]. Therefore, land taxation should be implemented to determine land value appreciation for investing in the construction of public facilities for public benefits, which is conductive to achieving social justice and sustainable development [13-15]. Although a strong practical demand exists, the relevant research on land valuation and taxation information model proposal remains insufficient. Therefore, this domain should be further studied intensively.

Although land valuation and taxation have consistently been important components of the cadastre, the academic community of international land management science has been relatively late in studying the land valuation and taxation information model. Lemmen, van Oosterom et al. proposed the international standard LADM but included the external extension model of land valuation and land taxation in the appendix [5]. Nevertheless, the external extension model is relatively sketchy. In 2013, Cagdas developed an application domain extension to immovable property taxation on the basis of the The open geospatial consortium (OGC)CityGML standard to systematically organise the information supply and demand of various administrative entities of the Turkish land taxation [16]. The extension model adds classes and attributes suitable for taxation and valuation requirements into the OGC CityGML standard and further discusses the relationships and constraints between the classes. Although the extension study is not based on the LADM standard, this research remains a landmark investigation in this domain. In 2016, Cagdas et al. proposed a land valuation and taxation information model based on the LADM standard [8]. They likewise conducted systematic reviews of international and European standards related to land valuation and further conducted detailed discussions on international geographical information standards. They used these studies as bases to propose the LADM land valuation and land tax information model in detail, which is universally applicable. In this sense, Cagdas et al. plays a foundational role in this domain. In 2017, Kara et al. deepened the international land valuation and taxation information model on the basis of organising and discussing international mainstream geographic information standards, such as LADM and LandInfra [17]. Subsequently, Kara et al. conducted a national study of Turkey [18] and the Netherlands [19] based on the international model and the taxation and valuation laws of these countries, as well as further proposed detailed national models. They implemented the information model of land valuation and taxation on the basis of the European INTERLIS standard [20] and further implemented the database of land valuation and taxation model in Turkey [21]. Polat et al. used the analysis of the information requirements of municipal management in Turkey as basis to propose 
the main LADM extension models, such as land valuation and spatial planning [22]. Kobasa et al. discussed in detail the role of land valuation and taxation model [23]. Tomić et al. used the systematic analysis of various registration institutions and registration information in Croatia as bases to conduct a comprehensive evaluation of the applicability of land valuation and taxation information model of LADM in this country. They concluded a judgement of which attribute data in the model are available and unavailable in Croatia. Van Oosterom et al. and Lemmen et al. summarised the preceding studies and proposed academic suggestions, respectively, to improve the land valuation and taxation information model in the revised edition of LADM $[6,7]$.

The studies on land valuation and taxation information models have achieved beneficial results and created the internationally applicable information model through the effort of the academic community of international land management science. Researchers have conducted pilot studies in Turkey, the Netherlands and Croatia and initially tested the applicability of this model. Nevertheless, the existing studies continue to have the following four deficiencies. Firstly, the existing models from the perspective of taxation have focused on the model related to the property ownership tax and insufficiently concentrated on the model related to property transaction tax. Secondly, the majority of the valuation adjustment factors from the valuation perspective that are the concern of existing studies are micro- or small-scale factors, such as building factors. By contrast, macro- or large-scale factors, such as location or public facility factors, are relatively disregarded. Third, national empirical research and international applicability tests are insufficient. Fourth, although the existing models are proposed on the basis of international valuation standards, the taxation and valuation classes and their attributes are mainly adapted to the practical demands of Turkey's property tax. Therefore, the international applicability of the model remains insufficient. This study attempts to fill in the aforementioned research gaps.

The motivation of the current study is to propose a valuation and taxation information model that fulfils the practical demands of China's rural land reform. The proposed model will also promote data interaction between real estate registration agencies and taxation authorities, as well as improve collaborative management among the administrative departments. The research problem of this study is to propose a land valuation and taxation information model for RCL transaction according to the legal provisions and technical specifications related to land taxation and valuation in China. This research focuses on the problem of land valuation to adapt to property transaction tax and the role of large-scale factors, such as location, in land valuation. The present research scope is the relevant provisions of China's land value appreciation and deed tax laws related to the transfer of RCL. Land valuation and taxation play an important role in determining the value of RCL and have important theoretical and practical significance in alleviating social conflicts, promoting social sustainability and improving land governance performance. Given that China is a large developing and transitional economy, the Chinese case study is of immense significance to improve the international adaptability of land valuation and taxation information model.

\section{Methodology}

This study adopts a structured information system development methodology of land administration to propose a valuation and taxation information model of RCL in China (see Figure 1 and Table 1) [24-26]. In the methodology, the output of the previous step becomes the input of the next step. The first step is identifying the research problem. The research gaps are identified, and scientific questions are proposed through literature retrieval and review. This study used "land valuation", "land taxation" and "land administration" as keywords to retrieve journal and conference articles on Web of Science, Taylor and Francis, International Office for Cadastre and Land Records and other scientific literature retrieval engines. This research also used "land valuation", "land taxation", "cadastre" and "land Administration" as keywords (in Chinese) to retrieve scientific and technological books in the national library of China. The authors read titles and abstracts to remove duplicate and irrelevant scientific literatures, as well as read the closely relevant literature. Lastly, the scientific problem of this study is proposed through the literature review. The second step is analysing 
the existing models. The shortcomings and improvement direction of the models are identified through the systematic analysis of the existing models. The third step is analysing tax laws. The authors retrieved the relevant legal provisions with "the land value appreciation tax" and "the deed tax" as keywords (in Chinese) on the official websites of the China People's Congress (www.npc.gov.cn), State Council (www.gov.cn) and Ministry of Finance (www.mof.gov.cn). Furthermore, the authors conducted a structured analysis of the retrieved results. The fourth step is assessing the valuation specifications. The authors retrieved the relevant technical specifications with "valuation" and "standard" as the keywords (in Chinese) on the official websites of the China Standardization Commission (www.sac.gov.cn), China Institute of Real Estate Appraisers and Agents (www.cirea.org.cn) and China Real Estate Valuers and Agents Association (www.creva.org.cn). The fifth step is proposing the model. The object-oriented development method was adopted to propose the land valuation and tax information model of RCL in China on the basis of the preceding legal and technical constraints and specification requirements of LADM. The sixth step is drawing the conclusions. The proposed model was compared with the research questions to check whether the model systematically responds to the scientific problem.

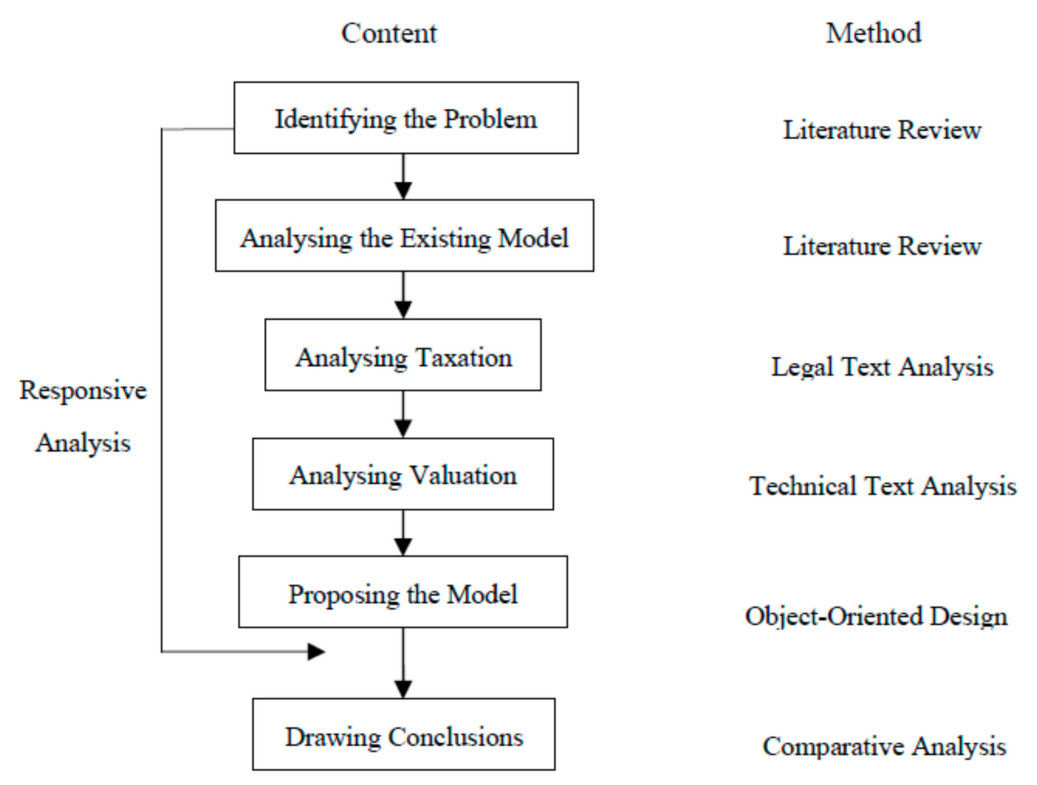

Figure 1. Research methodology.

This paper is structured according to the methodology. The first section is the introduction, which introduces the research background and identifies the scientific problem through the literature review. The second section is the research methodology, which describes the research inputs, processes and expected results of this study. The third section is the existing model analysis, the main content of which is to conduct a systematic analysis of the existing models and further identify the direction of model improvement. The fourth section is the analysis of tax law. Accordingly, tax subject, object, base, rate and amount of land value appreciation and deed tax are organised through the structured analysis of legal texts. The fifth section is the valuation standard analysis. This section organises the methods, parameters and processes of the land classification and valuation of construction and agriculture lands. The sixth section is the model proposal. On the basis of the preceding research results, the information model of the valuation and taxation of RCL is proposed by adjusting and supplementing classes and associations in the existing models. The seventh section is the research conclusion. The research model and problem are compared to verify whether the research model is effective in responding to the scientific problem, thereby enabling us to draw the research conclusion. 
Table 1. Research methodology.

\begin{tabular}{|c|c|c|c|}
\hline Process & Method & Input & Output \\
\hline $\begin{array}{l}\text { Identifying the } \\
\text { scientific problem }\end{array}$ & Literature review & $\begin{array}{l}\text { Journal articles, conference articles, } \\
\text { scientific and technical books }\end{array}$ & Scientific problem \\
\hline $\begin{array}{l}\text { Analysing the } \\
\text { existing models }\end{array}$ & Literature review & Journal articles, conference articles & Research deficiencies \\
\hline Analysing tax laws & $\begin{array}{l}\text { Text analysis of } \\
\text { legal documents }\end{array}$ & $\begin{array}{l}\text { Documents of laws and } \\
\text { administrative regulations }\end{array}$ & Legal restraints \\
\hline $\begin{array}{l}\text { Analysing the } \\
\text { valuation specifications }\end{array}$ & $\begin{array}{c}\text { Text analysis of } \\
\text { technical specifications }\end{array}$ & $\begin{array}{l}\text { Technical specifications of real } \\
\text { estate valuation }\end{array}$ & Technical restraints \\
\hline $\begin{array}{l}\text { Proposing the } \\
\text { information model }\end{array}$ & Object-oriented design & Legal and technical restraints & Information model \\
\hline $\begin{array}{l}\text { Drawing } \\
\text { the conclusions }\end{array}$ & Comparative analysis & Research problem and model & Conclusions and discussions \\
\hline
\end{tabular}

\section{Review of Existing Information Models}

Lemmen, van Oosterom et al. designed the LADM model in response to "the vision of Cadastre in 2014" (i.e., modelling land administration and promoting cross department interconnection) $[27,28]$. The LADM model successfully became an international standard in 2012 [29]. In this standard, the extension of land valuation and taxation is reserved in the form of an appendix [8]. However, ISO 19152:2012 only provides the framework design for land valuation and taxation extension with only a few substantial contents [29]. This framework reserves necessary placeholders for further research in the future. Cadgas, Kara et al. substantially extended the land valuation and taxation extension classes and proposed the fiscal extension module on the basis of an in-depth study of international and European valuation and geographic information standards [8-17]. The following section briefly reviews the core and extension classes of LADM and the core classes in the fiscal extension module.

\subsection{Core and Extension LADM Classes}

LADM is an abstract conceptual information model of land administration (cadastre) [5-30]. Moreover, LADM corresponds to Jo Henssen's "man-right-land" model and has three packages: (1) party, (2) administrative and (3) spatial unit packages and surveying and presentation sub package (subordinate package of the spatial unit package) [31]. The party package and its core class LA_Party correspond to "man" in the "man-right-land" model and are used to record the identity information of right holder [5]. The administrative package and its core classes LA_RRR and LA_BAUnit correspond to "right" in the "man-right-land" model and are used to record property legal information [5]. The spatial unit package, surveying and presentation sub package and their core classes LA_SpatialUnit, LA_LegalSpaceBuildingUnit and LA_LegalSpaceUtilityNetwork correspond to "land" in the "man-right-land" model and are used to record spatial and surveying information [5]. The external extension classes of LADM encompass ExtParty, ExtPhysicalUtilityNetwork, ExtAddress, ExArchive, ExtValuation, ExtTaxation, ExtLandUse, ExtLandCover and other extension classes [29]. The ExtValuation and ExtTaxation extension classes are closely related to this study. The ExtValuation class simply composes such attributes as value, valueDate and valueType. The ExtTaxation class constitutes such attributes as amount, taxDate and taxType. Evidently, the ExtValuation and ExtTaxation extension classes contain relatively limited information but provide the necessary placeholders for future research (see Figure 2) [17]. 


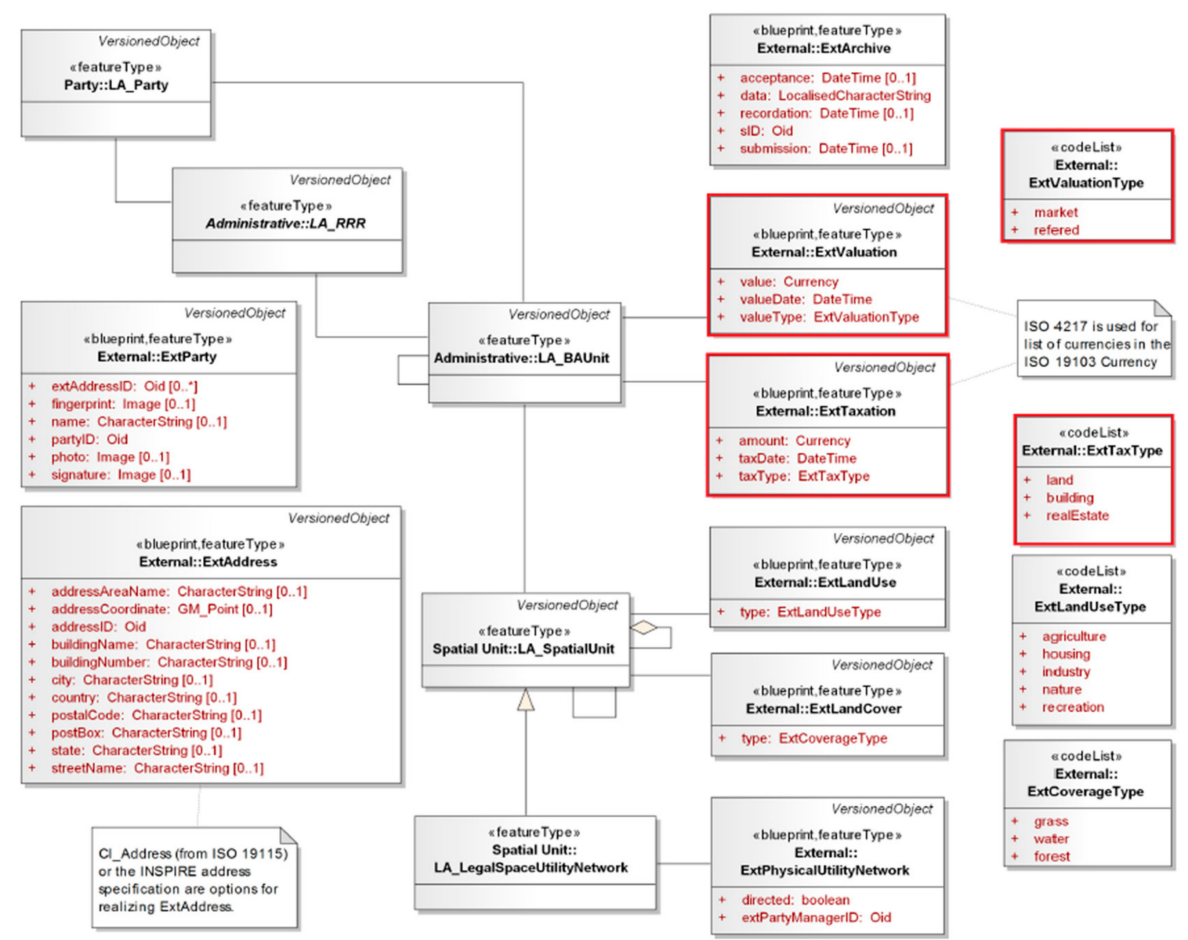

Figure 2. Core and external land administration domain model (LADM) classes. Source: ISO, 2012.

\subsection{Core Classes of the Fiscal Extension Module}

To interconnect the land administration system with the valuation and tax system, Cadgas et al. proposed the core classes of Fiscal Extension Module on the basis of the framework structure of LADM (see Figure 3) [8].

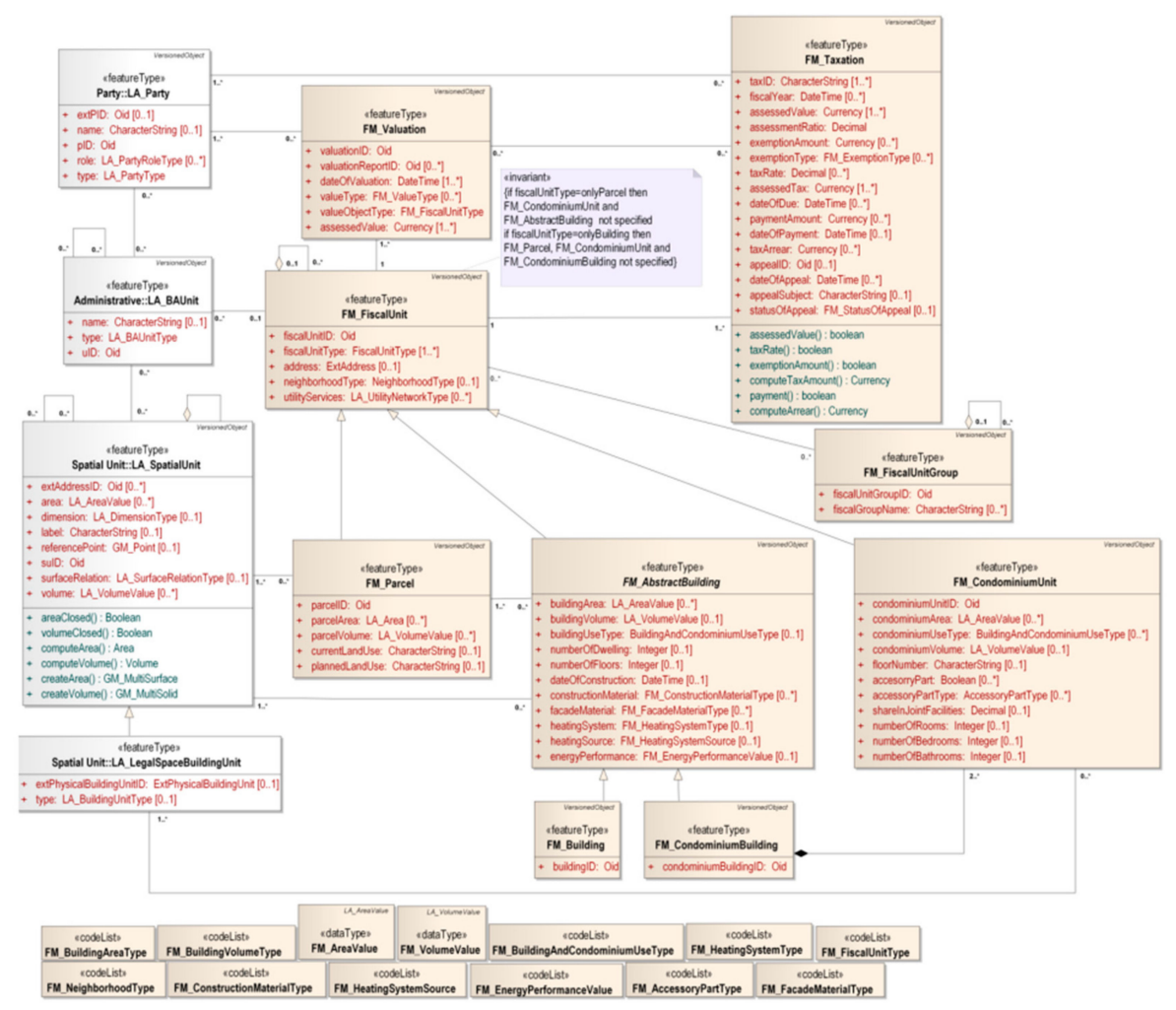

Figure 3. Core classes of the fiscal extension module. Source: Cagdas et al. [8] 
ExtValuation and ExtTaxation are extended to FM_Valuation and FM_Taxation. Numerous attributes and methods related to valuation and taxation are added into the core classes according to the technical requirements of the international and European valuation regulations [8-17]. The fiscal extension module adds several core classes that correspond to the core classes in LADM. FM_FisUnit is an extension class corresponding to LA_BAUnit that records peripheral environment information, such as neighbourhood types and utility services. The FM_FisUnitGroup, which is a group class of FisUnit, is proposed to adapt to the fact that valuation and taxation practices are done either in blocks or grades. Extension classes are added in the module corresponding to the LA_SpatialUnit, such as FM_Parcel, FM_AbstractBuilding and FM_CondominiumUnit. FM_Parcel records information on the parcel, such as current and planned uses. FM_AbstratBuilding mainly records information on buildings. Relatively extensive property information is added in the class, such as building area, building volume, building use type, number of floors, number of households, building materials, facade materials, heating system, heating source and power efficiency. FM_AbstratBuilding further derives two subclasses, namely, FM_Building and FM_CondominiumBuilding. FM_CondominiumUnit records information on condominium, such as area, volume, use type, number of rooms, number of bedrooms and number of bathrooms. FM_CondominiumUnit is a concept corresponding to LA_LegalSpaceBuildingUnit.

Some auxiliary classes are added in the fiscal extension module to enhance technical support for land valuation (see Figure 4) [8-17]. FM_Valuation derives two subclasses, namely, FM_SinglePropertyValuation and FM_MassPropertyValuation, which are used to support the appraisal of single and block real estate, respectively. Market information on real estate transactions should be collected to support valuation practice. FM_TransactionPrices is used to record the time point information of transaction price, whereas FM_TimeSeriesData is used to record the time series information of transaction. This information will provide sufficient sample data for the valuation.

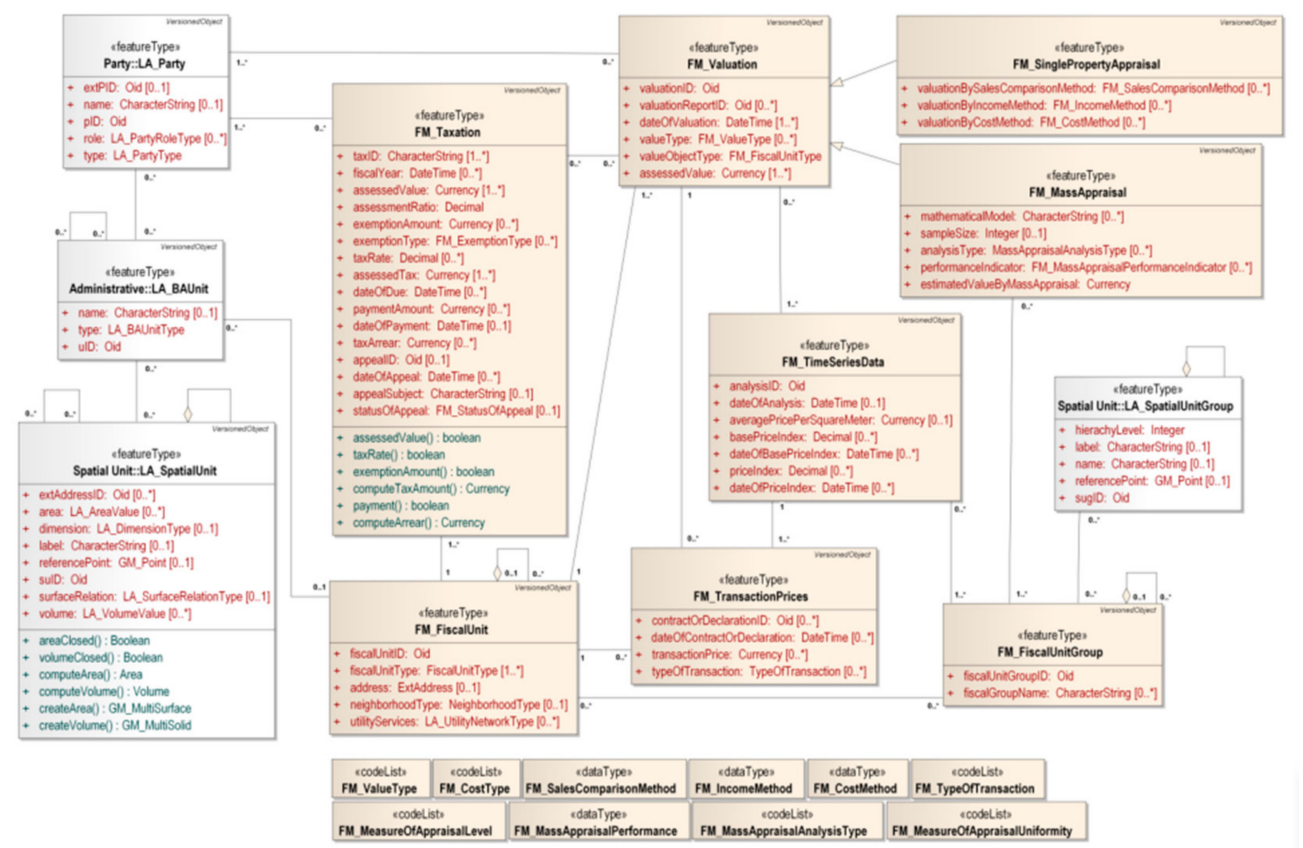

Figure 4. FM_Valuation and related classes of the fiscal extension module. Source: Cagdas et al. [8].

A brief review of the Fiscal Extension Module shows that the information of FM_AbstratBuilding and FM_CondominiumUnit of the building are fully extended. Thus, the information of small-scale real estate appraisal is relatively sufficient. However, FisUnitGroup, FisUnit and FM_Parcel, which record the environmental and parcel information of real estate, are relatively brief. Macro-influencing factors, such as the environment and land parcel of real estate, are important factors determining land price and become an indispensable component of land evaluation. Therefore, the current study fully extends FM_FisUnit and FM_Parcel. Moreover, this research further expands the FM_Taxation to support the 
administration of land value appreciation tax and deed tax. Additionally, China has special tax and invoice registration for taxpayers. Therefore, this study extends ExtParty to the class FM_Party to record tax registration information.

\section{Tax-Related Legal Regulations}

\subsection{Related Tax Conception}

China's tax laws are a hierarchical system [32]. A higher law has higher legal effect than a lower law. Moreover, higher law stipulates the legal provisions of principles and framework, whereas lower law stipulates operational and detailed provisions [32]. The corresponding legal provisions are laws, administrative regulations, departmental regulations and administrative documents from top to bottom. The key documents are identified through a systematic retrieval of legal documents. The law related to the taxation of RCL is the "Law on Taxation Administration" [32]. The involved administrative regulations constitute the "Administrative Regulations on Land Value Appreciation Tax" [33] and "Administrative Regulations on Deed Tax" [34]. This domain does not address departmental regulations. Many administrative documents are involved. Amongst the comparatively important ones are the "Implementation Rules for the Administrative Regulations on Land Value Appreciation Tax" [35], "Implementation Measures for the Collection and Use Administration on the Land Appreciation Adjustment Fees of Rural Collective Construction Land" [36] and "Implementation Rules for the Administrative Regulations on Deed Tax" [37].

The "Law on Taxation Administration" stipulates that the competent tax authorities are the Ministry of Finance and its subordinate agency (i.e., State Bureau of Taxation), which are responsible for tax registration, verification, liquidation and collection [32]. Tax authorities conduct tax registrations for taxpayers, such as business opening, modification, suspension, resumption, cancellation and outgoing registrations. Tax registration adopts uniform social credit or identity code (i.e., identity card number or passport number) to identify taxpayers. Therefore, a change in taxpayers' names does not affect taxation. Tax authorities shall verify and levy taxes on business entities and individuals. Uniform invoice coding and registration administration are employed as the major technical means of verification and collection. Business entities and individuals shall complete the tax business registration as a prerequisite to obtain invoices from tax authorities. Invoices shall be issued to the customer when a business or an individual provides goods or services and receive income.

Taxpayers involved in the transfer of RCL shall apply for tax registration and acquire corresponding tax invoices [32]. The taxes involved in the transfer of RCL mainly encompass land value appreciation $\operatorname{tax}$ (LVAT) and deed tax (DT) [33,34]. Both taxes are property transaction taxes, which are levied in the process of real estate transfer. From the perspective of procedural law, taxes should be declared, liquidated and levied according to the legal procedures stipulated in the "Law of Taxation Administration" [32]. From the perspective of substantive law, tax payment shall be conducted according to the tax subject, object, base and rate stipulated in the LVAT and DT laws [33,34]. The following structured analysis of tax subject, object, base, rate and amount are related to LVAT and DT (see Figure 5) [31]. Note that the tax subject in this study refers to the businesses or individuals directly responsible for tax payment under the tax law. The tax object refers to the object of tax obligation. Tax base refers to the standard of tax calculation or the legal measurement standard of the amount of tax object. The tax rate refers to the proportion of the tax base [32]. 


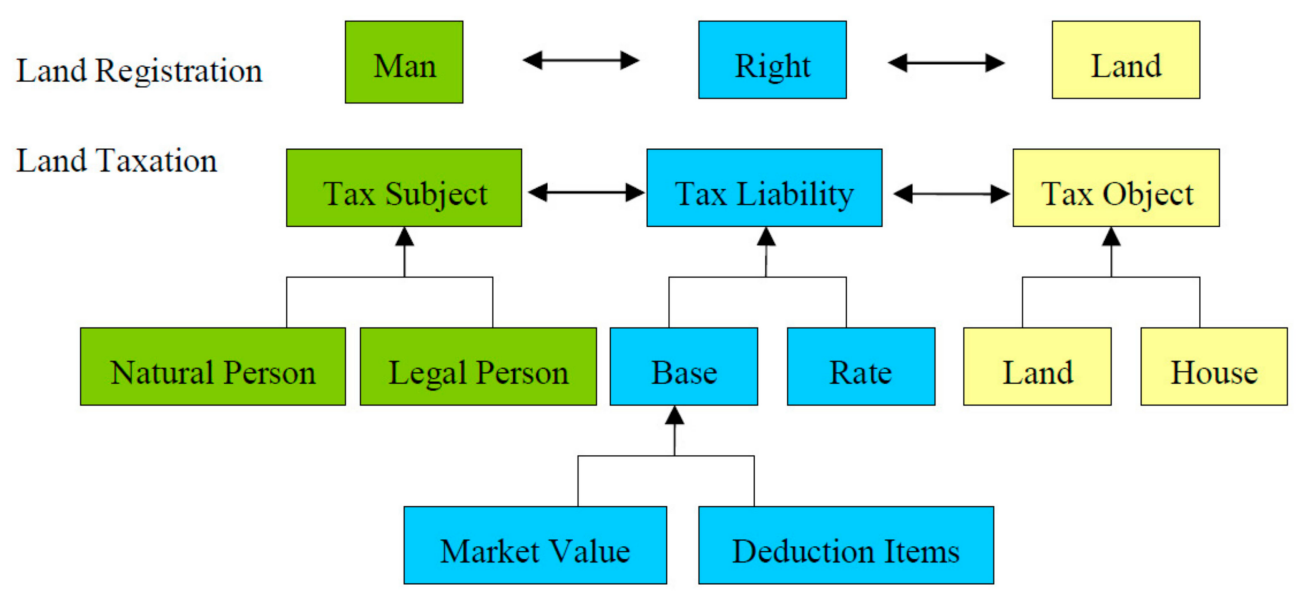

Figure 5. Framework of land taxation in China.

\subsection{Land Value Appreciation Tax}

After the reform and opening up, China gradually established the land and housing market [9]. As a transitional economy, China adopts a dual track land law system. In urban areas, a relatively mature land marketand housing market have been gradually established by adopting the resource allocation mode of market economy [11]. The Constitution and Property Law stipulate that land in urban areas shall be owned by the state. Thus, it has the right to use land that is transferred in the land market of urban areas. Moreover, the Constitution and Property Law stipulate that a house or structure in an urban area is allowed to be owned by the public or individuals. Thus, property ownership is transferred in the real estate market in urban area. Additionally, the Urban Real Estate Administration Law and Property Law formulate an integral principle. That is, land use right and property ownership shall be an integrated transfer and registration. The state council promulgated the "Administrative Regulations on Land Value Appreciation Tax" to curb real estate speculation and social differentiation between the rich and poor in urban areas [33]. The planned economic system for rural land and housing has been implemented for a long time and the transfer of land and housing was further restricted in rural communities [9]. As urbanisation and industrialisation are gradually advanced, rural areas are gradually marginalised and hollowed out [10]. Consequently, rural areas are increasingly poor and destitute. To revitalise the countryside, China's central government have attempted to open up rural land and housing markets in some pilot areas since 2016. The central government formulates land policies to attract external funds, talents and projects into the countryside to build rural infrastructure and restore the vitality of rural development [11]. As a response, the Ministry of Finance and Ministry of Land and Resources promulgated the "Implementation Measures on the Collection and Use Administration of Land Value Appreciation Adjustment Fees of Rural Collective Construction Land" and levied land value appreciation adjustment fees (LVAF) in rural pilot areas [35]. Thus, two markets and two taxation modes take shape in urban and rural areas. After the pilot program, the central government attempts to formulate a unified policy of market construction, right protection and tax collection in urban and rural areas. Therefore, LVAT in urban areas and LVAF in rural areas should be unified into the new LVAT that is generally applicable in urban and rural areas (see Figure 6). As a response, the standing committee of The National People's Congress (NPC) commissioned the Ministry of Finance to issue a draft of the LVAT law, which attempts to transform the legal provisions on LVAT from an administrative regulation into a law. The following structured analysis of the preceding three legal documents is from the perspectives of tax subject, object, base and rate. 


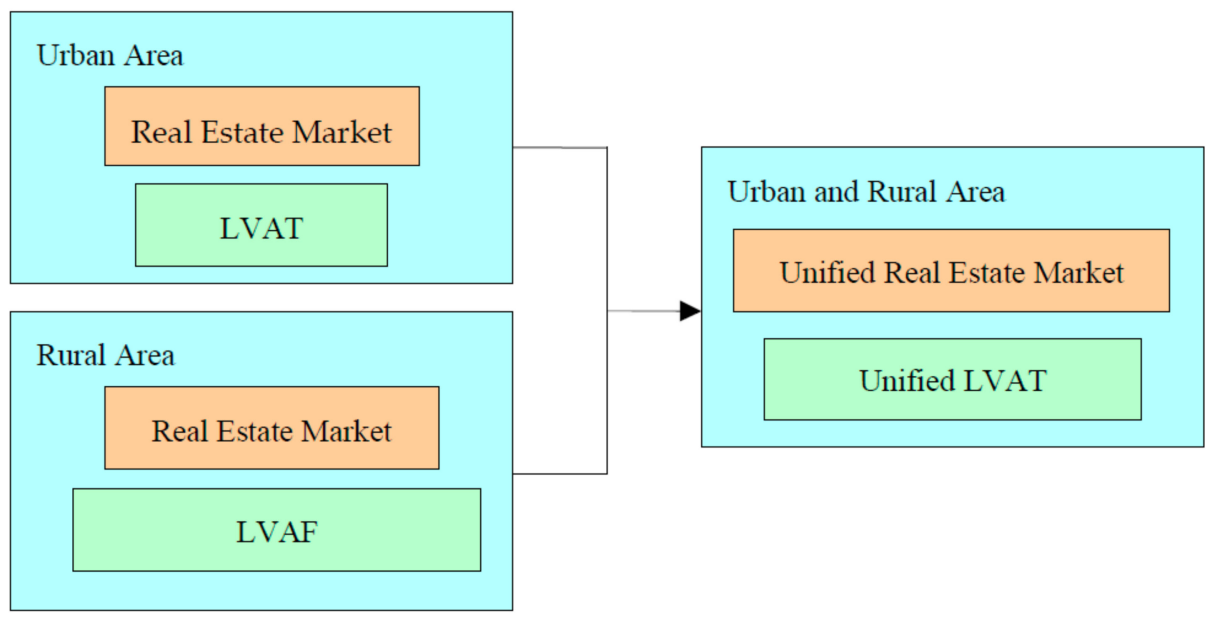

Figure 6. Change of land value appreciation taxation mode.

\subsubsection{Administrative Regulations on LVAT}

Tax subject: Any organisation or individual who transfers the right to use the state-owned land and its attached buildings and other objects and gain income from them (Article 1) [33].

Tax object: The right to use state-owned land, its buildings and attachments (Article 2).

Tax base: Land value appreciation or the balance of the income derived from the transfer of real estate after deducting the amount of the deduction items (Article 4). The income derived from the transfer of real estate shall include monetary, physical and other types of income (Article 5). The deduction items include (Article 6): (1) the cost paid for the acquisition of the right to use the land, (2) cost and expense of land development, (3) cost and expense of new buildings and supporting facilities or the appraisal price of old buildings, (4) taxes related to the transfer of real estate and (5) other deduction item stipulated by the Ministry of Finance.

Tax rate: Progressive tax rate of four levels of excess rate (Article 7). (1) The tax rate shall be 30\% on the part where the appreciation does not exceed $50 \%$ of the amount of the deduction items (ADI). (2) The tax rate shall be $40 \%$ on the part where the appreciation exceeds $50 \%$ and does not exceed $100 \%$ of ADI. (3) The tax rate shall be $50 \%$ on the part where the appreciation exceeds $100 \%$ and does not exceed $200 \%$ of ADI. (4) The tax rate shall be $60 \%$ on the part where the appreciation exceeds $200 \%$ of ADI.

Tax amount: tax amount $=$ tax base $\times$ tax rate.

\subsubsection{Implementation Measures on LVAF}

Tax subject: Transferor, leaser, investor and re-transferor of the right to use RCL (Article 5) [36].

Tax object: Existing RCL, the use of which is limited to industrial, mining storage, commercial, service and other business uses stipulated by comprehensive land use planning and urban and rural planning (Article 3).

Tax base: (1) Normal accounting. The tax base is appreciation from the entry into the land market or transfer of RCL (Article 6). The income from land appreciation refers to the net income from the entry into the market of RCL, after deducting the acquired cost and the land development expenditure; and the net income from the re-transfer, after deducting the acquired cost and the land development expenditure (Article 6). If verifying the cost of acquiring land for market entry or retransfer is not possible, the average cost of RCL may be stipulated according to the regional average cost of land acquisition (Article 9). (2) Simple accounting. Total transaction price (Article 9).

Tax rate: (1) Normal accounting. Adjustment fees are levied on $20 \%$ to $50 \%$ of the appreciation. (2) Simple accounting. Adjustment fee are levied on a certain proportion of the total transaction price (Article 9). 
Tax amount: (1) Normal accounting. tax amount $=$ added value $\times$ tax rate. (2) Simple accounting, tax amount $=$ land price $\times$ tax rate.

\subsubsection{Law on LVAT (draft)}

Tax subject: Any organisation or individual who transfers the right to use the land, its attached buildings and other objects, and gain income from them (Article 1). Note that the right holder of RCL is included in the tax subject according to Article 1.

Tax object: The right to use land, its buildings and attachments (Article 2). Note that the right to use RCL is included in the tax object according to Article 2.

Tax base: (1) Normal accounting (Article 6). The rules are similar to the stipulations of the administrative regulations on LVAT. (2) Simple accounting (Article 10). The rules are similar to the stipulations of the interim measures on LVAF.

Tax rate: (1) Normal accounting (Article 7). The rules are similar to the stipulations of the administrative regulations on LVAT. (2) Simple accounting (Article 10). The rules are similar to the stipulations of the interim measures on LVAF.

Tax amount: tax amount $=$ tax base $\times$ tax rate.

\subsection{Deed Tax}

The "Administrative Regulations on Deed Tax" stipulates that the deed tax will be levied on the heir of the real estate when real estate transfer occurs [34]. Deed taxes are only levied in urban areas because of the long-term implementation of the planned economy in rural areas and the fact that real estate in rural areas cannot be traded in the market. Given that land reform is carried out in pilot areas, Article 21 of the implementation measures on LVAF stipulates that the deed tax shall be levied together with LVAF in pilot areas [36]. The relevant legal provisions of the deed tax can be predicted to be implemented in rural areas after the complete establishment of the rural real estate market.

Tax subject: Any organisation or individual who has received the transfer of a land and housing (Article 1). The transfer of land and house includes the following actions: (1) transfer of state-owned land use right; (2) transfer of land use right, including sale, gift and exchange; (3) housing sales; (4) housing donation and (5) housing exchange.

Tax object: The right to use the land, its buildings and other attachments (Article 1).

Tax base: (1) The transaction price, in the case of the grant of the right to use state-owned land, sale of land use rights and sale of houses. (2) Assessed value verified by tax authorities with reference to the market price of land use right and house in the case of gift of land use right and house. (3) The difference between the prices of the exchanged land use rights and houses in the case of the exchange of land use rights and houses (Article 4).

Tax rate: $3 \%-5 \%$. This rate shall be stipulated by the people's province, autonomous region and municipality governments directly under the central government in accordance with the actual conditions (Article 3).

Tax amount: tax amount $=$ tax base $\times$ tax rate.

\section{Technical Specifications on the Valuation of RCL}

The administrative regulations on LVAT and DT stipulate that the transaction price of real estate is generally used as the basis for determining the tax amount. However, tax authorities are allowed to entrust a qualified third-party neutral valuation agency to assess the market value of the real estate for determining the tax amount in the following two cases. (1) The administrative regulations on LVAT stipulates that the tax amount shall be calculated through evaluation if the transaction price of real estate is concealed or falsely reported, the amount of deduction items provided is not true and the transaction price of real estate transferred is lower than the valuation price of real estate and there is no legitimate reason (Article 4) [33]. (2) The administrative regulations on DT stipulates that the exchange value of real estate shall be verified with reference to the market price of sale of land use right and 
house and when land use right and house gift is granted. The valuation difference of land use right and house exchanged shall be evaluated with reference to the market price of land use right and house when exchanging land use right and house (Article 4) [34]. In practice, there are several scenarios for the determination of land evaluation agencies. (1) The scenarios of land use right (house ownership) being transferred in the primary land market. If the land transaction is conducted by bidding, auction or listing at the public resource transaction agencies held by the government, the transaction price shall be used as the tax base. If the transfer is done by voluntary agreement between the transaction parties and the applied transaction price is lower than the bench price published by the government, the land administration authority shall employ a qualified third-party evaluation agency to determine the tax base. (2) The scenarios of land use right (house ownership) being transferred in the secondary land market. If the transaction price is equal to or higher than the benchmark price published by the land administration authority, the transaction price shall be used as the tax base. If the transaction price is lower than the benchmark price published by the land administration authority, the land administration authority shall employ a qualified third-party evaluation institution to determine the tax base. Note that the information system of the evaluation agency and the land administration authority exchange data via the Internet.

\subsection{Real Estate Valuation}

Through systematic retrieval, the valuation standards formulated by international organisations mainly constitute international and European valuation standards [38,39]. The three valuation methods recommended by international organisations encompass the sales comparison, income capitalisation and cost methods (see Table 2). The sales comparison method aims to compare the characteristics of the real estate to be estimated with other several similar real estates recently sold, as well as to obtain the market value of the real estate to be estimated through adjustment of the time of sale, location and physical characteristics of the compared real estates. The income capitalisation method converts the present or prospective stream of income derived from property into capital value through several approaches (e.g., direct and yield capitalisations). The cost method requires an estimate of the current cost to reproduce or replace a building and the extent to which buildings have depreciated. International organisations have further standardised the working procedures for single and mass appraisal of property. The applicable valuation standards in China encompass the "Real Estate Valuation Standard", "Urban Land Valuation Standard" and "Agricultural Land Valuation Standard" and "Technical Specifications on Land Valuation of Right to Use Collective Land". The China Institute of Real Estate Appraisers and Agents (CIREA) led the development of the "Real Estate Valuation Standard" [40]. The China Real Estate Valuers and Agents Association (CREVA) led the formulation of "Urban Land Valuation Standard" [41], "Agricultural Land Valuation Standard" [42] and "Technical Specifications on Land Valuation of Right to Use Collective Land" [43]. The appraisal of housing market value generally uses the technical specifications formulated by CIREA. The appraisal of land market value generally uses the technical specifications formulated by CREVA. CIREA and CREVA have completely absorbed the technical constraints of the international and European valuation standard. China's two valuation standard organisations have separately supplemented the residual and benchmark price adjustment methods. The residual method is a process of evaluating the market value of land use right. Its main idea is to estimate the value of real estate without the development cost, necessary development profits and transaction taxes and the remaining item after deduction is the market value of land use right. The idea of the bench price adjustment method is similar to the sales comparison method. This concept aims to compare the average conditions of the real estate to be estimated with the evaluation area and obtain transaction price of the real estate to be estimated after the adjustment of the time of sale, location and physical characteristics. Therefore, the valuation methods of the residual and bench price adjustment method should be added to FM_SinglePropertyAppraisal and FM_MassApraisal according to the technical constraints of the valuation specifications. 
Table 2. Valuation standards and methods formulated by international and Chinese associations.

\begin{tabular}{cccccc}
\hline & $\begin{array}{c}\text { Sales } \\
\text { Comparison }\end{array}$ & $\begin{array}{c}\text { Income } \\
\text { Capitalisation }\end{array}$ & Cost & Residual & $\begin{array}{c}\text { Bench Price } \\
\text { Adjustment }\end{array}$ \\
\hline IVS & $\sqrt{ }$ & $\sqrt{ }$ & $\sqrt{ }$ & & \\
EVS & $\sqrt{ }$ & $\sqrt{ }$ & $\sqrt{ }$ & & \\
CREVS & $\sqrt{ }$ & $\sqrt{ }$ & $\sqrt{ }$ & $\sqrt{ }$ & $\sqrt{ }$ \\
CULVS & $\sqrt{ }$ & $\sqrt{ }$ & $\sqrt{ }$ & $\sqrt{ }$ & $\sqrt{ }$ \\
CALVS & $\sqrt{ }$ & $\sqrt{ }$ & $\sqrt{ }$ & $\sqrt{ }$ & $\sqrt{ }$ \\
CSVRL & $\sqrt{ }$ & $\sqrt{ }$ & $\sqrt{ }$ & $\sqrt{ }$ & $\sqrt{ }$ \\
\hline
\end{tabular}

Note: (1) International Valuation Standards (IVS), (2) European Valuation Standards (EVS), (3) China Real Estate Valuation Standard (CREVS), (4) China Urban Land Valuation Standard (CULVS), (5) China Agriculture Land Valuation Standard (CALVS), (6) China Specifications on Valuation of the Rural Land Use Right (CSVRL) and (7) $\sqrt{ }$ means include.

Note that the sales comparison and income capitalisation methods are considerably suitable for outskirts of a city or town or where the real estate market is substantially mature. Cost, residual and bench price adjustment methods are considerably suitable for remote rural or rural areas with a premature real estate market. Additionally, the sales comparison and income capitalisation methods are more suitable for the market valuation of residential, commercial and service lands. Cost, residual and bench price adjustment methods are considerably applicable to the market valuation of land for industry and tourism [40,41]. It is noted that this study adopts evaluation methods and procedures for the purpose of taxation as stated in various above regulations such as International Valuation Standards (IVS), European Valuation Standards (EVS) and China Real Estate Valuation Standard (CREVS). For the tax base valuation of LVAT, the normal accounting method is adopted to evaluate the income obtained by the taxpayer from the transfer of real estate and ADI [33]. Deduction items include the amount paid for obtaining the right to use the land, cost and expense of developing the land, cost and expense of new houses and supporting facilities or valuation price of old houses and buildings and the tax related to the transfer of real estate [33]. For the accounting of each item, appropriate valuation methods shall be selected according to specific conditions $[40,41]$. The amount paid for obtaining the right to use the land is generally set as the price for obtaining the right to use the agricultural land during the land use period. Therefore, its appraisal is applicable to the relevant provisions of agricultural land valuation standard [42]. For simple accounting, applicable methods are generally adopted to evaluate the market value of real estate. For deed tax, it is similar to adopt applicable methods to evaluate the market value of real estate $[34,40,41]$. To provide data sources to the valuation of real estate, a large number of real estate transaction databases are needed. The potential databases include those on real estate registration, housing transaction contract record, land transaction contract record and agricultural land transfer contract record. The development and utilisation of the aforementioned transaction data can provide reliable data support for the tax base assessment of real estate.

\subsection{Land Classification}

CREVA developed the land classification standards in addition to the land valuation standards. These standards include the "Urban Land Classification and Grading Standard" [44], "Agriculture Land Classification Standard" [45] and "Technical Specifications on Land Valuation of the Right to Use Collective Land". The Ministry of Land and Resources (former Ministry of Natural Resources) has launched the task of land classification, built numerous land classification databases and required the work results to meet the requirements of the preceding technical standards. The classification results of rural land were fully applied in the pilot areas of rural land reform when the zones and levels of land taxation were delimited. Land classification results shall be fully applied in the tax base valuation of rural real estate to further improve the accuracy of the appraisal results. Particularly, the regional background information provided by the land classification shall be fully utilised when applying the sales comparison approach with regional factor adjustment. Given the lack of classification standard on 
rural construction land, the "Technical Specifications on Land Valuation of the Right to Use Collective Land" requires the adoption of the provisions on the classification factor system from "Urban Land Classification and Grading Standard" to determine the classification factor system of RCL. The Urban Land Classification and Grading Standard stipulates that the influencing factor system of construction land valuation constitutes the following aspects [44]: (1) prosperity, (2) transportation, (3) infrastructure, (4) environment and (5) demographic features. Table 3 lists the first and second level factor systems of construction land. The Agriculture Land Classification and Grading Standard stipulates that the influencing factors of the agricultural land classification shall include the following aspects [45]: (1) local climate, (2) topography and geomorphology, (3) soil, (4) water resources, (5) infrastructure, (6) convenient features for cultivated land, (7) location and (8) transportation. Table 4 lists the first and second level factor systems of agriculture land. All classification factors are scored using the percentage system. The standardised scores of these factors can be applied to adjustment of general and regional aspects when conducting the valuation of rural construction and agriculture land. Moreover, information from the land classification database should be applied to spatial classes, such as FM_FisUnitGroup and FM_Parcel.

Table 3. Influencing factor system of the construction land classification.

\begin{tabular}{cl}
\hline First Level & \multicolumn{1}{c}{ Second Level } \\
\hline C1 Prosperity & C11 Business and service prosperity \\
C2 Transportation & C21 Road accessibility, C22 Bus convenience, C23 External traffic \\
C3 Infrastructure & Convenience, C24 Road network density \\
C4 Environment & C41 Living facilities, C32 Public facilities \\
C5 Demographic features & C43 Green space coverage, C44 Natural environment \\
\hline
\end{tabular}

Table 4. Influencing factor system of the agriculture land classification.

\begin{tabular}{cl}
\hline First Level & \multicolumn{1}{c}{ Second Level } \\
\hline A1 Local climate & A11 Temperature, A12 Accumulated temperature, A13 Precipitation, A14 \\
& Evaporation, A15 Acid rain, A16 Disaster climate, A17 Frost-free period \\
A2 Topography and geomorphology & A21 Geomorphic type, A22 Topographic position, A23 Elevation, A24 Slope, \\
& A25 Slope direction, A26 Erosion degree \\
A3 Soil & A31 Soil depth, A32 Obstacle depth, A33 Soil texture, A34 Profile \\
A4 Water resources & configuration, A35 Soil pH, A36 Soil salinity \\
A5 Infrastructure & A41 Groundwater depth, A42 Water guarantee rate, A43 Water quality \\
& A51 Forest network rate, A52 Irrigation guarantee rate, A53 Drainage, A54 \\
& Field road, A55 Field power supply \\
A6 Convenient features for cultivated land & A61 Plot size, A62 Plot shape, A63 Plot flatness, A64 Plot elevation \\
A7 Location & difference, A65 Farming distance \\
A8 Transportation & A71 The farmer's market influence \\
& A81 Road accessibility, A82 External traffic convenience \\
\hline
\end{tabular}

\section{Land Valuation and Taxation for Chinese Rural Collective Construction Land}

This section conducts further study on land valuation and the taxation model in China on the basis of the fiscal extension module proposed by Cagdas and Kara and the legal constraints of tax and the technical constraints of valuation presented in Sections 4 and 5, respectively (see Figure 7) $[8,18]$. Land valuation and taxation model can be decomposed into three components, namely, "man-liability-land", which correspond to the "man-right-land" structure of land registration [5,31]. The tax subject part mainly presents the subject information of tax entities and individuals recorded by tax authorities during tax registration. The tax liability part mainly reflects the tax base and its valuation information. The tax object part mainly describes the spatial information of real property, such as physical location, economic location, infrastructure, and physical form. The fiscal extension module is formulated according to the international and European evaluation standards and has international applicability. Therefore, the current study will utilise and deepen the 
fiscal extension module. Note that silver presents the core classes in LADM, light yellow represents the core classes in the fiscal extension module and red presents the core classes of the article.

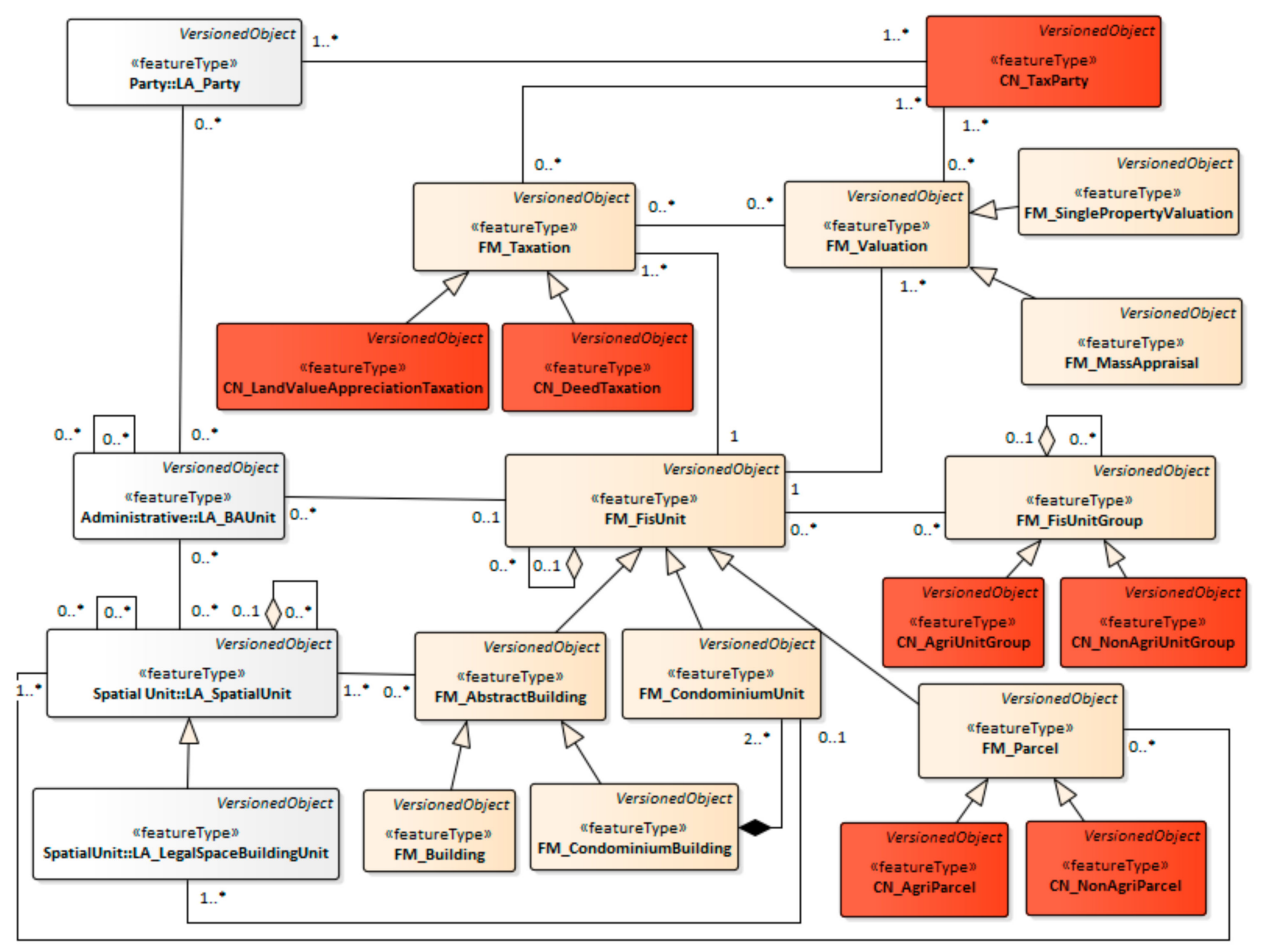

Figure 7. Fiscal extension module for the rural collective construction land in China.

\subsection{Tax Subject}

The CN_TaxParty class is derived from the external class ExtParty of LADM to present the registration information of taxpayers' identity recorded by tax authorities (see Figure 8) [29]. According to the "Law on Taxation Administration", "Implementation Regulations of the Law on Taxation Administration" and "Administrative Measures for the Tax Registration" [46], tax registration information includes the following aspects: taxpayer name, taxpayer identification number, legal representative in charge, business address, registration type, accounting type, business scope and issued date. A taxpayer identification number is unique. (1) For taxpayers who have received the organisation code, their taxpayer identification number is 15 digits, which is composed of six digits of administrative division code and nine digits of organisation code in the place where the taxpayer is registered. (2) The organisation with owner's identity certificate is the valid individual identity card (i.e., the individual industrial and commercial households that have not obtained the organisation code certificate), The taxpayer identification number is composed of the identity certificate number and the two-digit sequence code. The tax administration department is connected with the other administrative departments via the Internet, such as institutional establishment, market supervision, civil affairs and public security departments, to ensure the consistency of taxpayers' information. To coordinate the administration of departments, the national standards commission issued the "Code Rules for the Uniform Social Credit Code for Legal Persons and Other Organizations (GB 32100-2015)" [47] and "Code Rules for Citizenship Number (GB 11643-1999)" [48] to standardise the rules for the credit code of organisations and identity code of individuals. The cooperation of these departments is conducive to the verification of family tax deductions and exemptions. To levy tax on real estate, the taxation department should cooperate with the real estate registration department to exchange the information of taxpayer registration and real estate registration. Since 2015, the organisation code has been implemented as a national uniform code, which is conducive to cross-network interaction between the two departments. The real estate registration department often updates the taxpayer's identity 
information when the real estate is transferred. Therefore, the identification information recorded by real estate registration department is more dated than the identification information recorded by tax registration department. This aspect will require substantial cooperation between the two departments to facilitate online updating of identity information. Additionally, invoices are registered by tax authorities for administration [32,46]. CN_Invoice is proposed to fulfill the administrative requirement. The registered attributes, such as invoice ID, customer name, customer TaxID, payment amount, deduction amount, are added into CN_Invoice (see Figure 8).

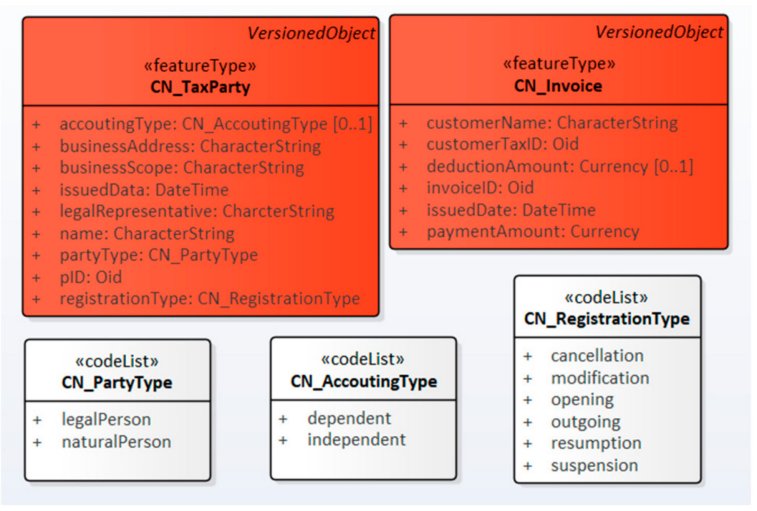

Figure 8. Classes and code lists related to tax party.

\subsection{Tax Liability}

For the tax liability part, FM_Taxation is extended into two parts, namely, CN_DeedTaxation and CN_LandValueAppreciationTaxation, according to the requirements of taxation administration of CRL in China (see Figure 9). CN_DeedTaxation records real estate transactions of CRL in China. CN_LandValueAppreciationTaxation mainly records the information of real estate transaction (evaluation) price and deduction items. The attributes involved in general tax payment have been covered by the FM_Taxation class. This study added the following attributes according to the tax information management requirements of the Chinese tax law. Additional attributes, such as openingBank, bankAccountNumber, and taxAuthority, are added in the CN_DeedTaxation and CN_LandValueAppreciatinTaxation (see Figure 9) [46]. Additionally, CN_LandValueApppreciationTaxation adds the following attributes (see Figure 9): (1) transfer real estate income (transactionValueAmount), (2) amount paid for obtaining the right to use the land (firstDeductionItemsAmount), (3) real estate development costs (secondDeductionItemsAmount), (4) cost and expense of new buildings and supporting facilities or the appraisal price of old buildings (thirdDeductionItemsAmount), (5) taxes related to the transfer of real estate (fourthDeductionItemsAmount) and (6) other deductions (fifthDeductionItemsAmount) [33]. CN_DeedTaxation and CN_LandValueAppreciationTaxation can calculate the taxBase and taxRate fields on the basis of the above attributes.
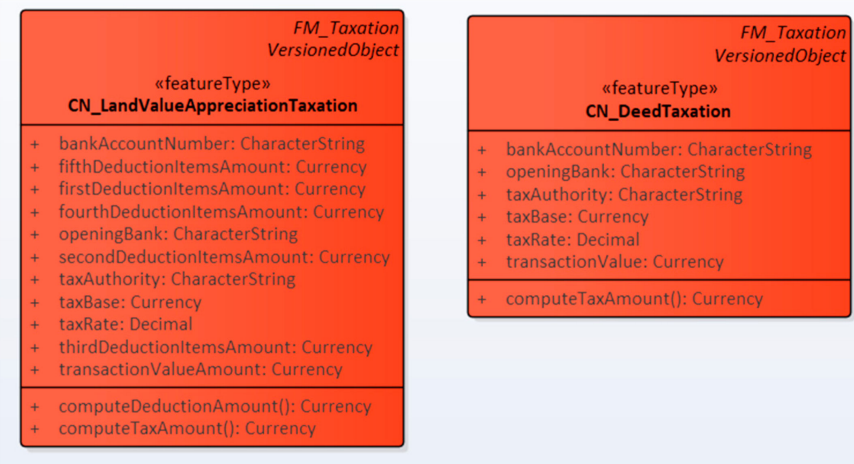

Figure 9. Taxation classes for the rural collective construction land. 


\subsection{Land Valuation}

FM_Valuation and its subclass are extended according to the restraints of China's valuation technical specifications (see Figures 10 and 11). The CN_SinglePropertyAppraisal class is derived from FM_SinglePropertyAppraisal, which is supplemented with the residual valuation method (see Figure 11) [40-42]. The residual method is not proposed in the international and European valuation standards but proposed in the major valuation standards of China. The reason is mainly to adapt to the Chinese Constitution and Property law provisions. That is, China's land ownership must implement the public policies [49]. The real estate market is limited to transfer land use right and housing ownership. The residual method is an applicable method to evaluate land use right $[40,41]$. Given the total value of the real estate minus the replacement cost of the house and the necessary development costs, profits and taxes, the remaining part is the market value of the land use right. The valuation method is particularly applicable in the immature rural land market. Therefore, the study adds the residual method into the valuation model according to the requirement of China. The CN_LandBenchPriceValuation class was derived from FM_MassAppraisal to provide the technical support for the benchmark land price valuation method according to the needs of implementing mass real estate valuation in China (see Figure 11) [50]. To promote land taxation and market price macro-control, China has deployed the land classification of rural and urban agriculture and construction land every four to five years and evaluates the bench price of the classification or area. The appraisal agency may evaluate the price of a real estate through adjustment based on the bench price. The specific reason is to adopt a method similar to the market method to compare the real estate to be estimated with the benchmark conditions and to conduct the adjustment of the transaction period, general situation, regional situation and individual situation. CN_MarketData is derived from FM_TimeseriesData to provide an information source for valuation. The class CN_MarketData is conductive to making full use of the record data of agriculture land, rural collective construction land and rural housing transfer contracts (see Figure 11). The code list CN_TransactionType presents types of the record data of agriculture land, rural collective construction land and rural housing transfer contracts.

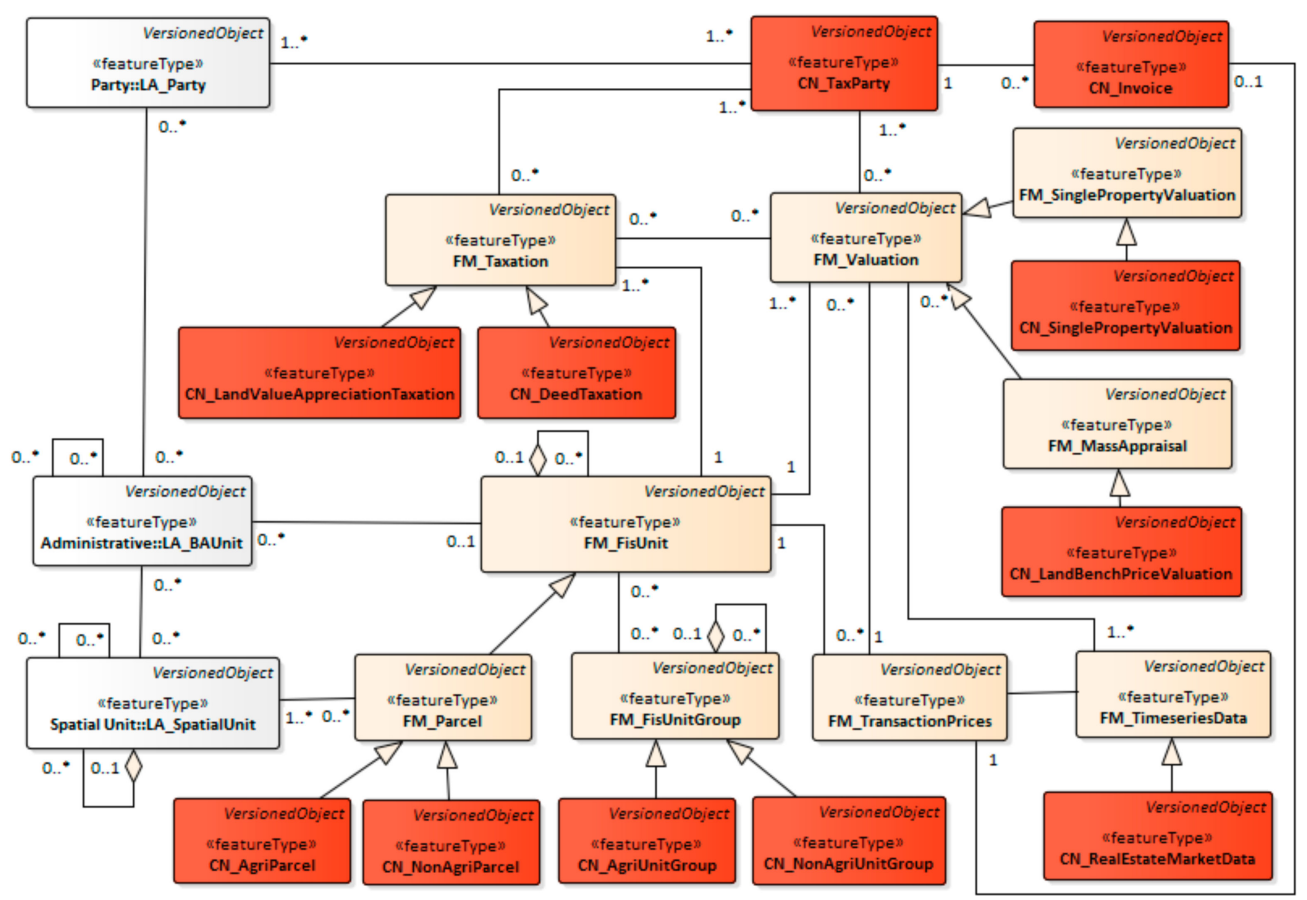

Figure 10. Valuation classes and related classes. 

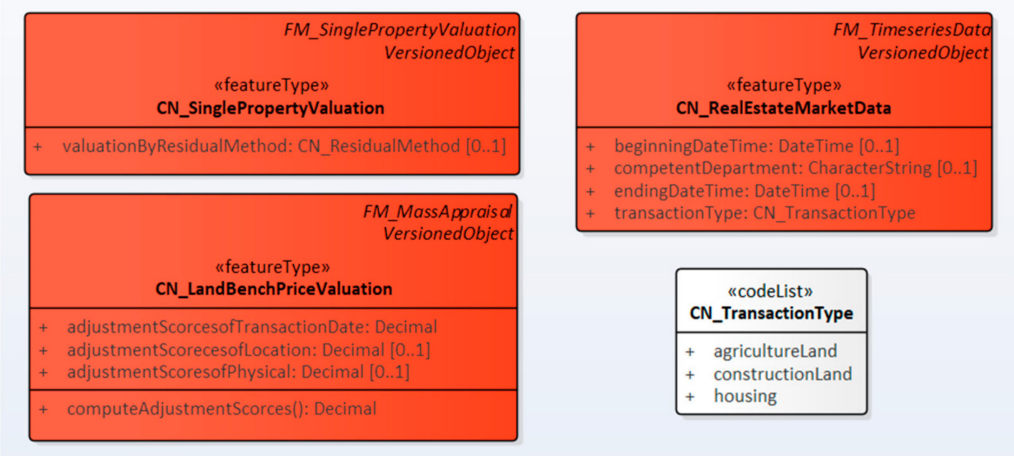

Figure 11. Valuation classes for the rural collective construction land.

\subsection{Tax Object}

The fiscal extension module provides detailed presentations of micro-geographic information, such as buildings and constructions. Therefore, the study supplements presentations of macro-geographic information of land according to the practical demands of valuation and taxation of RCL in China. On the basis of the valuation information provided by agriculture and rural construction land classification [44,45], CN_AgriFisUnitGroup and CN_NonAgriFisUnitGroup are derived from FM_FisUnitGroup, whereas CN_AgriParcel and CN_NonAgriParcel are derived from FM_Parcel. The large-scale agriculture land valuation factors are added into the $\mathrm{CN} \_$AgriFisUnitGroup class, such as A1 local climate (from A11 to A17), A2 topography and geomorphology (from A21 to A26), A5 infrastructure (from A51 to A55), A7 location (A71), and A8 transportation (from A81 to A82). The small-scale agriculture land valuation factors are added into the CN_AgriParcel class, such as A3 soil (from A31 to A36), A4 water resources (from A41 to A43) and A6 convenient features for cultivated land (from A61 to A65). The large-scale construction land valuation factors are added into CN_NonFisUnitGroup, such as $\mathrm{C} 1$ prosperity (C11), C2 transportation (from C21 to C24) and C5 demographic features (C51). The small-scale construction land valuation factors are added into CN_NonParcel, such as C3 infrastructure (from C31 to C32) and C4 environment (from $\mathrm{C} 41$ to $\mathrm{C} 44)$. The construction of tax object information is conductive to providing sufficient adjustment information for tax base valuation. Note that Figure 12 only illustrates the first level influencing factors and omits the secondary level ones due to the constraint of article length. Secondary influencing factors shall be added according to the actual demands in the development of the actual system. Data sources of some attributes such as parcelArea, parcelVolume, currentLandUse and plannedLandUse come from the land classification database.
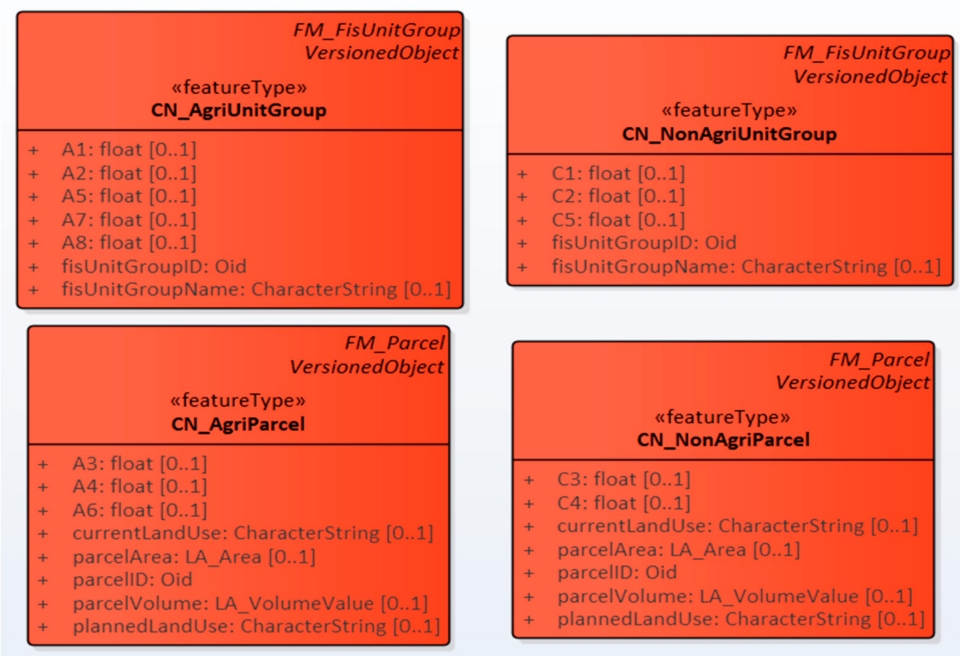

Figure 12. Classes related to the tax objects. 


\section{Conclusions and Discussion}

This research found that insufficient studies exist in the valuation and taxation information model of transaction tax and the large-scale influencing factors of valuation through systematic literature retrieval and review in the domain of the LADM valuation and taxation information model. The current study attempted to fill in the research gaps. The scientific problem of this study aimed to propose a land valuation and taxation information model of RCL according to the legal provisions of land tax and technical specifications of property valuation in China. Specially, the proposed model meets the requirements of transaction tax and considered the large-scale influencing factors. In response to the scientific problem, the current study conducted a structured text analysis of legal document texts related to land tax and technical specifications related to property valuation. On the basis of the preceding results, this study further proposed legal and technical constraints on land taxation and valuation of RCL in China. According to the preceding legal and technical constraints, the existing fiscal extension module was further extended to formulate a fiscal extension module for RCL in China. The proposed model conforms to the legal requirements and technical specifications, utilises various available data sources related to land valuation and taxation and plays an important role in implementing the value capture in the transfer of RCL. Evidently, China's land taxes are mainly transaction taxes. Moreover, large-scale valuation factors such as land classification are mainly considered in China's land tax base assessment. Therefore, this study effectively responds to the scientific problem proposed in the introduction section and fills in the research gaps in this domain. Furthermore, the proposed model arguably has important theoretical and practical significance in alleviating social conflicts and promoting social sustainability. Further research can be conducted in the following aspects. Firstly, the proposed model shall be modified and improved according to the land value appreciation tax law promulgated by the standing committee of NPC. Secondly, the progress of revising and improving the valuation and taxation information model of ISO ITC 211 should be tracked to improve the fiscal extension module for Chinese RCL. Third, the prototype of this model shall be realised. Furthermore, pilot studies shall be conducted in pilot areas of rural land reform. Lastly, the land taxation and valuation information model should be further expanded to China's urban areas until the country profile of the country's land taxation and valuation information model is proposed.

Author Contributions: Conceptualisation, Z.X. and Y.Z.; Formal analysis, Z.X., G.L. and R.L.; Funding acquisition, C.W.; Methodology, Z.X. and G.L.; Supervision, C.W.; Writing—original draft, Z.X.; Writing—review and editing, Y.Z.

Funding: This research was funded by the Key Program of National Social Science Foundation of China (Grant Nos. 14ZDA039).

Conflicts of Interest: The authors declare no conflict of interest.

\section{References}

1. Dale, P.F.; McLaughlin, J.D. Land Administration; Oxford University Press: Oxford, UK, 1999.

2. Williamson, I.; Enemark, S.; Wallace, J.; Rajabifard, A. Land Administration for Sustainable Development; ESRI Press: Redlands, CA, USA, 2010.

3. Zevenbergen, J. System of Land Registration: Aspects and Effects; Delft University of Techlonogy: Delft, The Netherland, 2002.

4. Larsson, G. Land Registration and Cadastral Systems: Tools for Land Information and Management; Wiley: New York, NY, USA, 1991.

5. Lemmen, C.; van Oosterom, P.; Bennett, R. The Land Administration Domain Model. Land Use Policy 2015, 49, 535-545. [CrossRef]

6. Lemmen, C.; van Oosterom, P.; Kalantari, M. Towards a New Working Item Proposal for Edition II of LADM. In Proceedings of the 7th International FIG Workshop on the Land Administration Domain Model, Zagreb, Croatia, 11-13 April 2018.

7. Van Oosterom, P.; Kara, A.; Kalogianni, E.; Shnaidman, A.; Indrajit, A.; Alattas, A.; Lemmen, C. Joint ISO/TC211 and OGC Revision of the LADM: Valuation Information, Spatial Planning Information, SDG Land 
Indicators, Refined Survey Model, Links to BIM, Support of LA Processes, Technical Encodings, and Much More on Their Way! In Proceedings of the FIG Working Week 2019, Geospatial Information for a Smarter Life and Environmental Resilience, Hanoi, Vietnam, 22-26 April 2019.

8. Çă̆das, V.; Kara, A.; van Oosterom, P.; Lemmen, C.; Isikdag, Ü.; Kathmann, R.; Stubkjær, E. An Initial Design of ISO 19152:2012 LADM Based Valuation and Taxation Data Model. In Proceedings of the ISPRS Annals of the Photogrammetry, Remote Sensing and Spatial Information Sciences, Athens, Greece, 20-21 October 2016; pp. 145-154. [CrossRef]

9. Ho, P. Institutions in Transition: Land Ownership, Property Rights, Social Conflicts in China; Oxford University Press: New York, NY, USA, 2005.

10. Long, H.; Li, Y.; Liu, Y.; Woods, M.; Zou, J. Accelerated Restructuring in Rural China Fueled by 'Increasing vs. Decreasing balance' Land-Use Policy for Dealing With Hollowed Villages. Land Use Policy 2012, 29, 11-22. [CrossRef]

11. Xu, Z.G.; Zhuo, Y.F.; Wu, C.F.; Li, G. Economic Interpretation and Jurisprudence Deduction of Tripartite Entitlement System of Rural Residential Land. China Land Sci. 2018, 32, 16-22. [CrossRef]

12. He, X.F. Logic of Land Rights II; Oriental Press: Beijing, China, 2013; pp. 17-19.

13. McAllister, P.; Shepherd, E.; Wyatt, P. Policy Shifts, Developer Contributions and Land Value Capture in London 2005-2017. Land Use Policy 2018, 78. [CrossRef]

14. Wang, J.; Samsura, D.A.A.; van der Krabben, E. Institutional Barriers to Financing Transit-Oriented Development in China: Analyzing Informal Land Value Capture Strategies. Transp. Policy 2019, 82. [CrossRef]

15. Enemark, S.; McLaren, R.; van der Molen, P. Land Governance in Support of the Millennium Development Goals; International Federation of Surveyors (FIG): Copenhagen, Denmark, 2010.

16. Çağdas, V. An Application Domain Extension to CityGML for immovable property taxation: A Turkish case study. Int. J. Appl. Earth Obs. Geoinf. 2013, 21, 545-555. [CrossRef]

17. Kara, A.; Çağdas, V.; Isikdag, Ü.; van Oosterom, P.; Lemmen, C.; Stubkjær, E. Towards an International Data Standard for Immovable Property Valuation. In Proceedings of the FIG Working Week 2017, Surveying the world of tomorrow-From digitalisation to augmented reality, Helsinki, Finland, 29 May-2 June 2017.

18. Kara, A.; Çă̆daş, V.; Işıkdağ, Ü.; van Oosterom, P.; Lemmen, C.; Stubkjær, E. Towards Turkish LADM Valuation Information Model Country Profile. In Proceedings of the FIG Working Week 2018, Istanbul, Turkey, 6-11 May 2018.

19. Kara, A.; Kathmann, R.; van Oosterom, P.; Lemmen, C.; Işıkda ğ, Ü. Towards the Netherlands LADM Valuation Information Model Country Profile. In Proceedings of the FIG Working Week 2019 Geospatial information for a smarter life and environmental resilience, Hanoi, Vietnam, 22-26 April 2019.

20. Kara, A.; Çağdaş, V.; Işıkdağ, Ü.; van Oosterom, P.; Lemmen, C.; Stubkjær, E. The LADM Valuation Module Based on INTERLIS. In Proceedings of the 7th LADM Workshop, Zagreb, Croatia, 11-13 April 2018.

21. Kara, A.; Işıkdağ, Ü.; Çağdaş, V.; van Oosterom, P.; Lemmen, C.; Stubkjær, E. A Database Implementation of LADM Valuation Information Model in Turkish Case Study. In Proceedings of the 7th LADM Workshop, Zagreb, Croatia, 11-13 April 2018.

22. Polat, Z.A.; Alkan, M. Design and Implementation of A LADM-Based External Archive Data Model for Land Registry and Cadastre Transactions in Turkey: A Case Study of Municipality. Land Use Policy 2018, 77, 249-266. [CrossRef]

23. Kobasa, M.; Shavrov, S.; Batura, O. ISO19152 Standard: Role of LA_ExtValuation Class for Land Administration. In Proceedings of the FIG Working Week 2018, Istanbul, Turkey, 6-11 May 2018.

24. Çağdas, V.; Stubkjaer, E. Design Research for Cadastral Systems. Comput. Environ. Urban Syst. 2011, 35, 77-87. [CrossRef]

25. Hespanha, J.P. Development Methodology for an Integrated Legal Cadastre. Ph.D. Thesis, TU Delft, Delft, The Netherlands, 2012.

26. Kalantari, M.; Dinsmore, K.; Urban-Karr, J.; Rajabifard, A. A Roadmap to Adopt the Land Administration Domain Model in Cadastral Information Systems. Land Use Policy 2015, 49, 552-564. [CrossRef]

27. Lemmen, C. A Domain Model for Land Administration; University of Twente, Delft University of Technology: Amsterdam, The Netherlands, 2012.

28. Kaufmann, J. Cadastre 2014: A Vision for a Future Cadastral System. In Proceedings of the 1st Congress on Cadastre in the European Union, Granada, Spain, 15-17 May 2002; p. 51. 
29. ISO. ISO 19152:2012 Geographic Information—Land Administration Domain Model (LADM); ISO: Geneva, Switzerland, 2012.

30. Paulsson, J.; Paasch, J.M. The Land Administration Domain Model—A literature survey. Land Use Policy 2015, 49, 546-551. [CrossRef]

31. Henssen, J.L.G. Basic Principles of the Main Cadastral Systems in the World. In Proceedings of the One Day Seminar Held during the Annual Meeting of Commission 7, Cadastre and Rural Land Management, of International Federation of Surveyors (FIG), Delft, The Netherlands, 16 May 1995.

32. Standing Commitee of National People's Congress. Law on Taxation Administration; Order 25 of the President of the People's Republic of China; Standing Commitee of National People's Congress: Beijing, China, 2015.

33. State Council. Administrative Regulations on Land Value Appreciation Tax; Order 138 of State Councile; State Council: Beijing, China, 1993.

34. State Council. Administrative Regulations on Deed Tax; Order 224 of State Councile; State Council: Beijing, China, 1997.

35. Ministry of Finance. Implementation Rules for the Administrative Regulations on Land Value Appreciation Tax; Administrative Document 6 of Ministry of Finance; Ministry of Finance: Beijing, China, 1995.

36. Ministry of Finance and Ministry of Land and Resources. Implementation Measures for the Collection and Use Administration on the Land Appreciation Adjustment Fees of Rural Collective Construction Land; Administrative Document 41 of Ministry of Finance; Ministry of Finance: Beijing, China; Ministry of Land and Resources: Beijing, China, 2016.

37. Ministry of Finance. Implementation Rules for the Administrative Regulations on Deed Tax; Administrative Document 52 of Ministry of Finance; Ministry of Finance: Beijing, China, 1997.

38. IVSC. International Valuation Standards; IVSC: London, UK, 2017.

39. TEGoVA. European Valuation Standards (EVS), 8th ed.; TEGoVA: Brussels, Belgium, 2016.

40. CIREA. Real Estate Valuation Standard (GB/T 50291-2015); CREVA: Beijing, China, 2015.

41. CREVA. Urban Land Valuation Standard (GB/T18508-2014); CREVA: Beijing, China, 2014.

42. CREVA. Agricultural Land Valuation Standard (GB/T28406-2014); CREVA: Beijing, China, 2012.

43. CREVA. Technical Specifications on Land Valuation of Right to Use Collective Land; Administrative Document 18 of CREVA; CREVA: Beijing, China, 2016.

44. CREVA. Urban Land Classification and Grading Standard (GB/T 18507-2014); CREVA: Beijing, China, 2014.

45. CREVA. Agriculture Land Classification Standard (GB/T 28405-2012); CREVA: Beijing, China, 2012.

46. State Bureau of Taxation. Administrative Measures for the Tax Registration. Order 36 of State Bureau of Taxation; State Bureau of Taxation: Beijing, China, 2014.

47. SAC. Code Rules for the Uniform Social Credit Code for Legal Persons and Other Organizations (GB 32100-2015); SAC: Beijing, China, 2015.

48. SAC. Code Rules for Citizenship Number (GB 11643-1999); SAC: Beijing, China, 1999.

49. Wong, V. Land Policy Reform in China: Dealing with Forced Expropriation and the Dual Land Tenure System. In Centre for Comparative and Public Law Occasional Paper No. 25; Faculty of Law, The University of Hong Kong: Hong Kong, 2014.

50. IAAO. Standard on Mass Appraisal of Real Property; International Association of Assessing Officers: Kansas City, MO, USA, 2013.

(C) 2019 by the authors. Licensee MDPI, Basel, Switzerland. This article is an open access article distributed under the terms and conditions of the Creative Commons Attribution (CC BY) license (http://creativecommons.org/licenses/by/4.0/). 